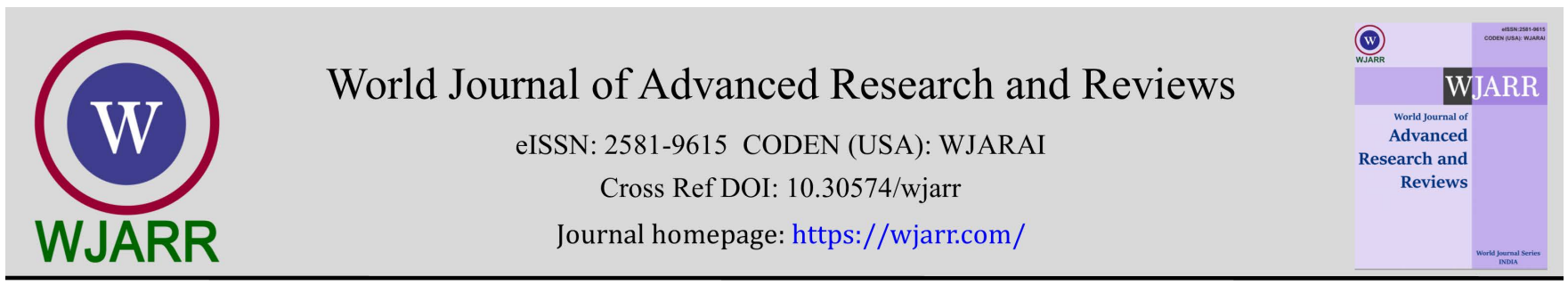

(RESEARCH ARTICLE)

\title{
ProviNeeds: A students support system for resource pooling
}

\author{
Aatmica Bajpai, Anuja Bokhare *, Ankur Srivastava and Sejal Agarwal \\ Symbiosis Institute of Computer Studies and Research Symbiosis International (Deemed University), Atur Centre, Gokhale \\ Cross Road, Model Colony, Pune-411016, Maharashtra State, India.
}

World Journal of Advanced Research and Reviews, 2022, 13(02), 438-447

Publication history: Received on 05 January 2022; revised on 20 February 2022; accepted on 22 February 2022

Article DOI: https://doi.org/10.30574/wjarr.2022.13.2.0139

\begin{abstract}
A broad range of students faces many issues in their day to day life due to less pocket money, transportation issues, time management, health issues and other many daily life issues. Many times student face the issue of buying resources and many times they are not able to fulfil their urgent needs due to many problems. ProviNeeds will be a student support system for resource pooling specifically for students, where they can pool extra resources, they can rent resources and can help other students in their local area by fulfilling their needs and by helping them. Students can put their requirements on this portal and the other student with that resource can respond and help that student. This system will be for a specific local area and only those local area students can interact and exchange resources and help each other.
\end{abstract}

Keywords: Student Support System; Barter System; Resource Pooling; ProviNeeds; Resource exchange

\section{Introduction}

College going students face a lot of issues in their day-to-day life. But one of the biggest problems faced by these students is financial issues, due to this they face a lot of problems in their college life. This problem arises due to limited pocket money, as the students have to manage their resources in this limited amount of money. This problem of limited pocket money gives rise to the problem of resource management and also has a direct impact on students learning activities. Resource Management plays an important role in our lives. Everything which has some value is demanded by people but students sometimes face huge problems due to a lack of important resources.

According to research students find a link between social connection and achieving relief from financial problems by developing a culture of borrowing and renting from friends. Some students need resources and then there are students who have extra resources and are not using them, so basically those resources are getting wasted. So the point over here is that it can connect these two different sides and create a system wherein the resources being wasted are utilized by the students who need them urgently. This study presents a solution for the discussed problem by proposing a student support system; a complete system for students wherein they can pool resources and earn extra pocket money.

ProviNeeds is the umbrella solution provider for the problem of lack of resources and financial issues faced by students. ProviNeeds will have the complete system of resource pooling, resource exchanging and community development and it will also act as a way of earning extra pocket money. ProviNeeds focuses on creating a clean and helpful environment for students where they can interact with each other, get to know each other, help each other and establish a connection.

\footnotetext{
${ }^{*}$ Corresponding author: A Bokhare

Symbiosis Institute of Computer Studies and Research Symbiosis International (Deemed University), Atur Centre, Gokhale Cross Road, Model Colony, Pune-411016, Maharashtra State, INDIA.
} 


\section{Literature Review}

Existing solutions might not focus on students separately but authors have identified similar problems in a different scenario and have given probable solutions for them. Review of previous research that has been done on the same problems is discussed in this section.

Rupak Rauniar et.al. Have researched about the concept of selling, buying and bidding of goods and services by using a $\mathrm{C} 2 \mathrm{C}$ online auction website. Authors have given this solution for the problem of lack of negotiation of price, urgent need of resources and for buyer's satisfaction and benefit. According to author using a well administered C2C website is an amazing idea for both buyers and sellers and this not save resources but will also be a very feasible option [1]. Marema Jebessa et.al. Have explored the challenges faced by students due to limited pocket money, how low pocket money affects their learning activities and how the students react to these challenges. In this study the authors suggested that the financial hardships faced by students can be solved giving short training to students on self-management and money management skills will help them in managing their pocket money [2]. John P. Shelton conducted a research on how renting is cheaper than owning and also saves resources. In this study the author explored the idea behind renting and how in urgent situations or during some kind of financial problems renting is a better solution then owning. In this study author also proved that owning and renting is totally dependent on the trends and prices but for a short period or for temporary use people should prefer renting [3]. Christina Pantazis et.al. Have conducted a research on how lack of basic necessities and finance affects the daily working and life of an individual. Authors have not given any probable solution for this problem but they have explained the complete mental and physical scenario of a person when he/she is not able to afford his/her basic and daily needs and how this affects their jobs, studies and leads to social exclusion [4]. Colin C. Williams in his research talks about a new emerging barter system which on a local and domestic level is a very good idea of saving resources and at the same time fulfilling needs and demands of the people. He has explained that how on global level barter system will affect the economy but then on local level it will help the people and at the same time lead to effective and efficient utilization of resources [5].

Sebla Demirkol et.al. Have explained about a multi-agent e-barter system. In this study it has been discussed about design and implementation of a multi-agent e-barter system which utilizes ontology-based comparison for bid matching. It's proved through study that formal representation and good decision-making was very important for agent mediated barter process and the behavioral model plays huge role in this barter system [6]. R. Chalal et.al. Have explained about the problem of effective bidding system and have given solutions. Authors have explained that how a company or project which was using bidding system should follow some stated ways and ideas in order for the bidding process to be successful. It was very important for the managers to understand the customer mindset and execute the bidding system; also to regulate the bidding system and keep it intact in order for it to work in an effective and efficient way [7]. Yanli Cao has researched about the use internet and use of technical means for leasing goods and services via internet and making this process affordable for both the supplier and the buyer. Authors has given the solution of a financing channel and smart manufacturing for leasing goods and services via internet [8]. Mark Roseland has talked about the issue of community development and proved that how community development helps in effective and efficient development of mental and physical health and how it promotes development of both society and surroundings of a person. Authors stated that having a community relationship and friend circle is important for an individual's healthy mind and how this also helps the individual in working more efficiently [9]. Tawanna R. Dillahunt et.al. Have explored about the online grocery and resource delivery system also talked about access to resources and other necessities in an easy and feasible way i.e. home delivery system. In this study it was found out that online resources delivery system was one of the most feasible ways to access resources and was at the same time feasible. According the research proposed online delivery system was affordable and amenable to multiple payment forms and could lead to healthier, faster and feasible selections [10].

Kenneth K. Boyer et.al. Have stated about how customer behavior was very important factor for an online shopping or resource exchange portal to be successful. Authors stated about development of a behavioral scoring model to predict future customer purchases in an online ordering application. The analysis illustrates the general applicability of predictive models of future customer purchases while also demonstrating the need to develop specific models for a specific environment [11]. Marcia Mkansi et.al. Have explored the idea of using a mobile application to fuel value-added services that power new e-grocery distribution models. Using apps and mobile technology to distribute required resources in a particular area. Mobile app as a solution given for bridging the infrastructural barriers, costs and complexities associated with e-grocery delivery operations [12]. P. Antoniadis et.al. Have explored about the problem of lack of peer-to-peer systems. There was a lack of resource sharing and cooperation among people. The solution of designing a mechanism where self-organized virtual communities can build relationship and foster was presented. The principals of game theory should be use to develops social and psychological approach and to foster peer to peer resource sharing [13]. Zoe Liberman et.al. Have researched about how resource sharing was an important aspect of 
human society, and how resources were distributed can provide people with crucial information about social structure. To test this suggestion authors conducted an experiment using both children and adult and later on from this experiment it was found that it was very important to have a relationship between the distributer and the favored, both of them need to know each other or at least have some little information and understanding of each other [14]. Marichris Diga et.al. Have stated in their research paper that how it was important for applications and websites that have the motive of developing public relation to use a social media environment. They gave the solution that having a social media environment was very important for community development website according to authors frequent users of social media tools reported greater perceptions of their own structural, expert and prestige power [15].

Alina Ciobanu et.al. Have explored that the personal, social, cultural and daily life problems faced by students. They have given the solution that college should include these general development problems in their curriculum. According to the research colleges should support and enhance student learning experience and they should promote social, cultural learning as well as help students in solving their personal issues [16]. Choi Shinae et.al. have discussed about the financial stress related problems of the students, authors have stated about how most of the college students face financial issues in their daily life. For this problem the solution of community financial counselling and financial advices to help them manage their finances and reduce their stress was suggested [17]. Martijn van Welie et.al. In their paper have offered a more specific solution for more effective cooperative work. Authors have given the solution of using webbased chatting application which can be used for any specific functionality of work, cooperative working and at the same time formal and informal communication [18]. Jih-Chun Yeh et.al. Have researched about how due to increase use of internet user a have started buying both new and second-hand products form online auction websites. The behavioral differences of people while using online auction websites was studied and have concluded saying that these are one of the most feasible and preferred websites [19]. Suhas Holla et.al. Have talked about problems faced while developing mobile based android applications and their rules. Authors have given layered solutions for developing an android based mobile application and have also explained server issues and rules and restrictions. The solution as the use of any android development software for easy and feasible development and using this software will also help the application in following desired rules and restrictions is suggested [20].

Boyer KK et.al. Presents the development of behavioral scoring models to predict future customer purchases in an online ordering application [21]. Mkansi M et.al. Have talked about a mobile application supported township and urban e-grocery distribution models that uses a software application (app) to bridge the infrastructural barriers, costs and complexities associated with e-grocery delivery operations in rural township areas [22]. Antoniadis P et.al. Have analyzed the benefits of enabling virtual communities to self-organize and introduce a novel research direction for providing incentives, required in this context, for resource sharing and cooperation [23]. Liberman Z et.al. Have talked about how resource sharing is an important aspect of human society, and how resources are distributed can provide people with crucial information about social structure [24]. Diga M et.al. Have talked about how public relations practitioners in this study who were more frequent users of social network sites and social media tools reported greater perceptions of their own structural, expert and prestige power [25]. Ciobanu A. In his research aims to emphasize the role and the importance that student services have in improving students' academic experience, with reference to various international studies. Understanding the concept of student services and their role contribute to the development of policies and strategies to support the academic field, drawing the necessary directions in improving service quality in higher education [26].

Choi S et.al. Has examined the issues with a sample of 554 college students who participated in financial counseling and found financial problems in various situations were each linked to increased financial stress. Financial stress was positively associated with having student loans and other forms of debt and was higher for female students and lower for those having investments. The purpose of this study was to understand how varied student financial situations impact financial counseling needs [27]. Van Welie M et.al. Have talked about how over the last years, online learning has gained significant popularity, and this trend is expected to continue in the future. Online learning is a multi-dimensional activity where each dimension should be adequately supported by an online learning system to provide a fruitful learning experience to its users [28]. Yeh JC et.al. Have conducted a study which included members of the Yahoo! and PChome online portal sites in Taiwan as research subjects. A web survey was conducted, and data were collected from a total of 313 bidders of online auctions. The casual model was validated using partial least squares (PLS) techniques [29]. Holla S et.al. Have talked about how in the advancing world of technology, Mobile applications are a rapidly growing segment of the global mobile market. Mobile applications are evolving at a meteor pace to give users a rich and fast user experience. In this paper, Android mobile platform for the mobile application development, layered approach and the details of security information for Android is discussed [30].

Further section explains about the methodology adopted for proposed system. 


\section{Material and methods}

The proposed idea is an umbrella solution provider for many daily life mental and physical problems faced by students. The students can log in on the portal and can search for a resource or upload a resource that they need. The portal also leads to effective and efficient utilization of resources as it gives users the option of resource pooling, buying and renting. The portal also helps in finding friends in the local area and establishing a community thus leading to community development.

Overall proposed student support system solves the problem of resource scarcity, less pocket money, and wastage of resources. This system is a complete organisation of online resource sharing and community development.

\section{Objective of the proposed methodology}

The basic objective of the system is to fulfil the needs and provide resources to students and also help them earn extra pocket money to overcome their financial problems. Other objectives of the study are:

- To utilize and pool resources effectively and efficiently.

- To help students in establishing a community and making friends in their local area.

- To establish a virtual environment for students where they can share their needs and get the resources they need.

- To make the most effective use of technology for creating a smooth working environment and an effective and efficient portal for students.

- The app will be designed to fulfil the needs of the student community.

- For the students to be able to buy a resource and they can also sell resources.

- For the students to be able to rent and pool the resource as per their need.

\section{Scope of the proposed methodology}

- This system/app is limited to a local area and all the societies and colonies in the local area can use this app.

- $\quad$ This system is specifically being designed for students.

- There is no fixed promise that the students will receive resources at their doorsteps, they can exchange them anywhere, anytime.

- $\quad$ The system/app will only provide resources that are imperishable and other daily life items.

\section{Proposed Methodology}

The students will first start by registering themselves on the system. By registering themselves they are connected to the students around their area. Student's data like name, phone number and email will be asked. And the data will be shared with the buyer only if the student agrees to share the data.

The application provides the student with three options that is to either buy or rent or pool a resource.

Once the student has registered themselves, they can either search for a resource or upload a resource. The student who is searching for the resource checks for the option listed by the seller-student which is either buy, rent or pool.

Once the resource to be bought is finalized to either pool or buy or rent the buyer-student gets the mail of confirmation with the details of the seller-student as allowed.

The student who wants to upload a resource can list their extra resource on the application to share it with other fellow students. Hence, the needs of the students will be fulfilled and at the same time, they can earn an extra passive income as well.

Among existing solutions available in literature, none of them is specifically for students, none of them connects students in a local area and very few of them have the barter system and resource pooling option. Therefore, proposed system is a completely new and unique idea made specifically for the student community to solve their day-to-day hurdles and help them in establishing a community. Figure 1. Shows the architectural flow of the system. 


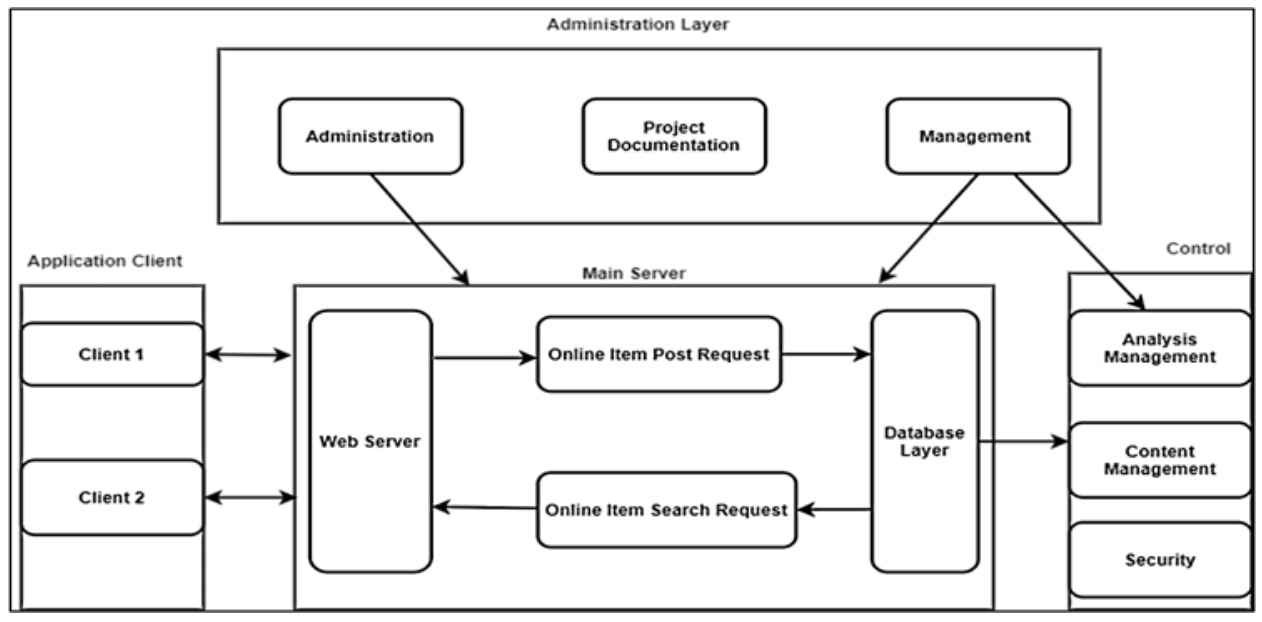

Figure 1 Architectural Flow of the portal

\section{Results and discussion}

This section focuses on the test evaluation and the results obtained. The observations are listed in Table 1 . All the various modules and functions in the proposed system were tested. Various system functions, its inputs, outputs and performance were tested. Various system scenarios were accounted for performance. Table 1 explains the same. Figure 2 to Figure 12 represents the various system function scenarios.

Table 1 Test Cases

\begin{tabular}{|c|c|c|c|c|c|}
\hline $\begin{array}{l}\text { Sr. } \\
\text { No }\end{array}$ & $\begin{array}{l}\text { Test Data } \\
\text { Items }\end{array}$ & Prerequisites & Test Case & Result & Test Comments \\
\hline 1. & $\begin{array}{l}\text { Main Page } \\
\text { Buttons }\end{array}$ & $\begin{array}{l}\text { The user } \\
\text { must've opened } \\
\text { the app to see } \\
\text { the main page. }\end{array}$ & $\begin{array}{l}\text { The login button and the sign } \\
\text { up on the main page should } \\
\text { navigate to the desired page } \\
\text { when the user clicks them. }\end{array}$ & $\begin{array}{l}\text { The buttons function } \\
\text { according to the } \\
\text { expected result and } \\
\text { navigate successfully. }\end{array}$ & None \\
\hline 2. & $\begin{array}{l}\text { Login } \\
\text { Button }\end{array}$ & $\begin{array}{l}\text { The user should } \\
\text { be a registered } \\
\text { user and should } \\
\text { have opened the } \\
\text { login page. }\end{array}$ & $\begin{array}{l}\text { The login button should } \\
\text { navigate to the search page } \\
\text { when the user clicks it }\end{array}$ & $\begin{array}{l}\text { The login button } \\
\text { functions according } \\
\text { to the requirement. }\end{array}$ & None \\
\hline 3. & $\begin{array}{l}\text { Login } \\
\text { Form }\end{array}$ & $\begin{array}{l}\text { The user should } \\
\text { be a registered } \\
\text { user and should } \\
\text { have opened the } \\
\text { login page. }\end{array}$ & $\begin{array}{l}\text { The form should take in data, } \\
\text { should have field validation, } \\
\text { it should show error if the } \\
\text { user is not registered and } \\
\text { should check the email } \\
\text { pattern. }\end{array}$ & $\begin{array}{l}\text { The login form is } \\
\text { performing all the } \\
\text { expected functions } \\
\text { properly. }\end{array}$ & $\begin{array}{l}\text { During the first test run the } \\
\text { login form did not send an } \\
\text { error for non-registered } \\
\text { user, but the error has } \\
\text { been identified the form is } \\
\text { functioning properly. }\end{array}$ \\
\hline 4. & $\begin{array}{l}\text { Sign Up } \\
\text { Button }\end{array}$ & $\begin{array}{l}\text { The user } \\
\text { should've } \\
\text { opened the sign } \\
\text { up page. }\end{array}$ & $\begin{array}{l}\text { The sign up button should } \\
\text { navigate to the user profile } \\
\text { page. }\end{array}$ & $\begin{array}{l}\text { The sign up button } \\
\text { functions according } \\
\text { to the requirement. }\end{array}$ & None \\
\hline 5. & $\begin{array}{ll}\text { Sign } & \text { Up } \\
\text { Form } & \end{array}$ & $\begin{array}{l}\text { The user } \\
\text { should've } \\
\text { opened the sign } \\
\text { up page. }\end{array}$ & $\begin{array}{l}\text { The form should take in data, } \\
\text { should have field validation, } \\
\text { it should show error if the } \\
\text { user data is not getting } \\
\text { recorded and should check } \\
\text { whether both the password } \\
\text { fields are matching or not. }\end{array}$ & $\begin{array}{l}\text { The sign up form is } \\
\text { performing all the } \\
\text { expected functions } \\
\text { properly. }\end{array}$ & $\begin{array}{l}\text { During the first test run the } \\
\text { form did not send an error } \\
\text { if user data was not being } \\
\text { recorded, but the error has } \\
\text { been identified the form is } \\
\text { functioning properly. }\end{array}$ \\
\hline
\end{tabular}




\begin{tabular}{|c|c|c|c|c|c|}
\hline 6. & $\begin{array}{l}\text { User } \\
\text { Profile } \\
\text { Page }\end{array}$ & $\begin{array}{l}\text { The user should } \\
\text { have navigated } \\
\text { through sign up } \\
\text { page to the user } \\
\text { profile. }\end{array}$ & $\begin{array}{l}\text { The user profile form should } \\
\text { take in data and the upload } \\
\text { resource and search button } \\
\text { should navigate to their } \\
\text { respective pages. }\end{array}$ & \begin{tabular}{|lr} 
The items on & user \\
profile page are \\
performing & their \\
function successfully.
\end{tabular} & None \\
\hline 7. & $\begin{array}{l}\text { Alert } \\
\text { Dialog Box }\end{array}$ & $\begin{array}{l}\text { The user should } \\
\text { have filled the } \\
\text { user profile } \\
\text { from in order } \\
\text { for the dialog } \\
\text { box to open. }\end{array}$ & $\begin{array}{l}\text { The alert dialog box should } \\
\text { show the alert message on } \\
\text { submission of user profile } \\
\text { form. }\end{array}$ & $\begin{array}{l}\text { The alert dialog box is } \\
\text { showing the alert } \\
\text { message properly. }\end{array}$ & None. \\
\hline 8. & $\begin{array}{l}\text { Search } \\
\text { Page }\end{array}$ & $\begin{array}{l}\text { The user should } \\
\text { have registered } \\
\text { in order to open } \\
\text { search page. }\end{array}$ & $\begin{array}{l}\text { The search field should take } \\
\text { in the search keyword and } \\
\text { should search for the } \\
\text { particular item. }\end{array}$ & $\begin{array}{l}\text { The search field is } \\
\text { performing its } \\
\text { function properly. }\end{array}$ & $\begin{array}{l}\text { During the first test run the } \\
\text { search field was not able to } \\
\text { retrieve the data, but the } \\
\text { issue has been resolved in } \\
\text { the second test run. }\end{array}$ \\
\hline 9. & $\begin{array}{l}\text { Product } \\
\text { Page }\end{array}$ & $\begin{array}{l}\text { The user } \\
\text { should've } \\
\text { opened the } \\
\text { particular } \\
\text { product page. }\end{array}$ & $\begin{array}{l}\text { The product page should } \\
\text { clearly display all the } \\
\text { information regarding the } \\
\text { product and the button } \\
\text { should navigate to the } \\
\text { confirm page. }\end{array}$ & $\begin{array}{l}\text { All the items on the } \\
\text { product page are } \\
\text { performing their } \\
\text { functions properly. }\end{array}$ & None \\
\hline 10. & \begin{tabular}{|l} 
Exit \\
Button
\end{tabular} & $\begin{array}{l}\text { The user } \\
\text { should've } \\
\text { completed all } \\
\text { the work and } \\
\text { navigated to the } \\
\text { exit page. }\end{array}$ & $\begin{array}{l}\text { On click of the exit button the } \\
\text { user should exit the portal } \\
\text { immediately. }\end{array}$ & $\begin{array}{l}\text { The exit button is } \\
\text { performing its } \\
\text { function properly. }\end{array}$ & None \\
\hline
\end{tabular}

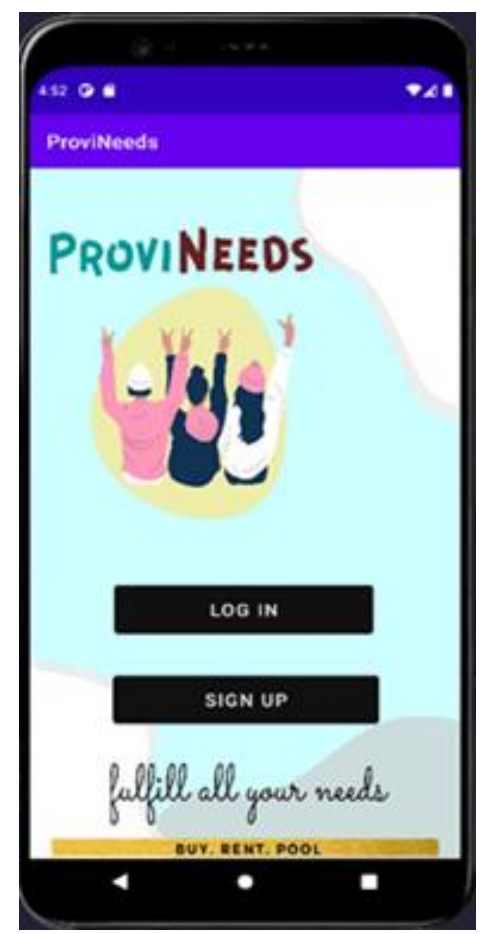

Figure 2 Main Page

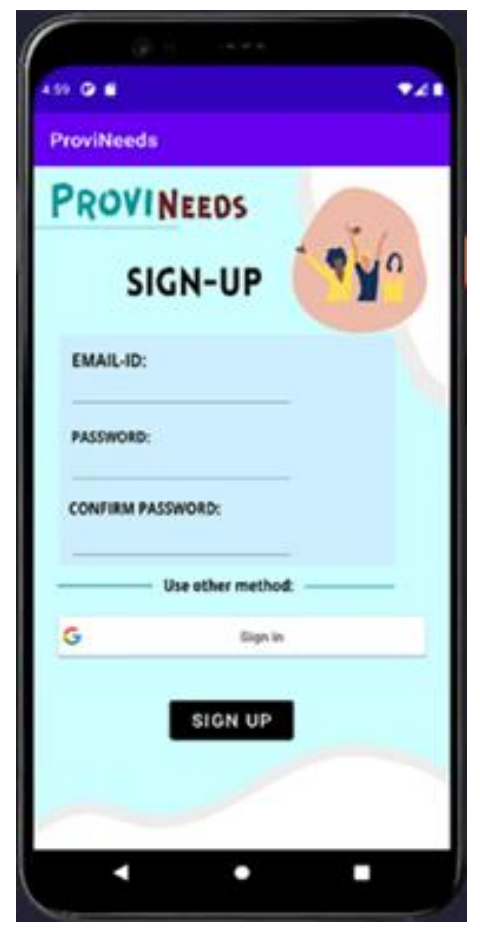

Figure 3 Sign UP Page

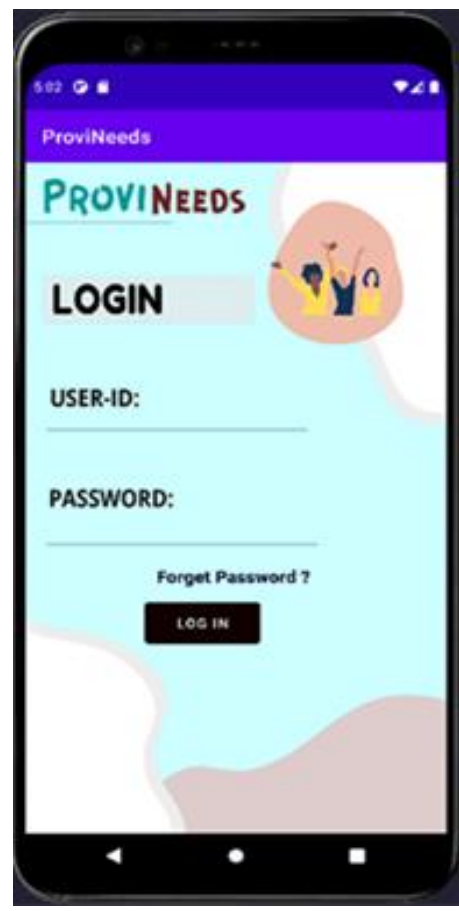

Figure 4 Login Page 


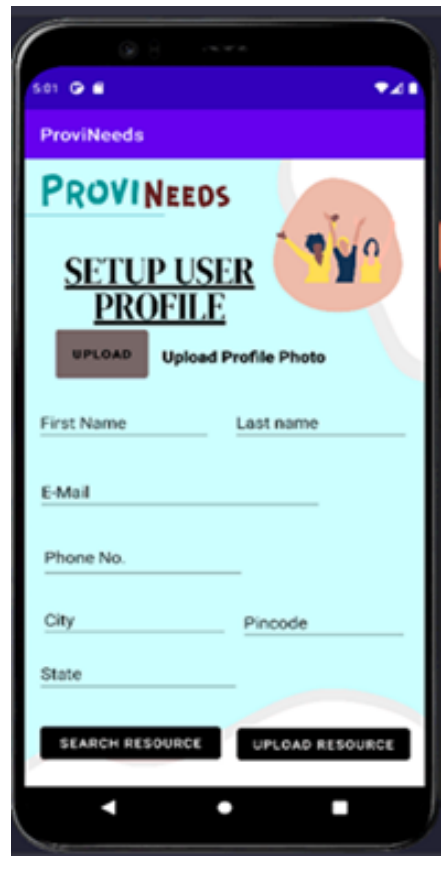

Figure 5 User Profile Page

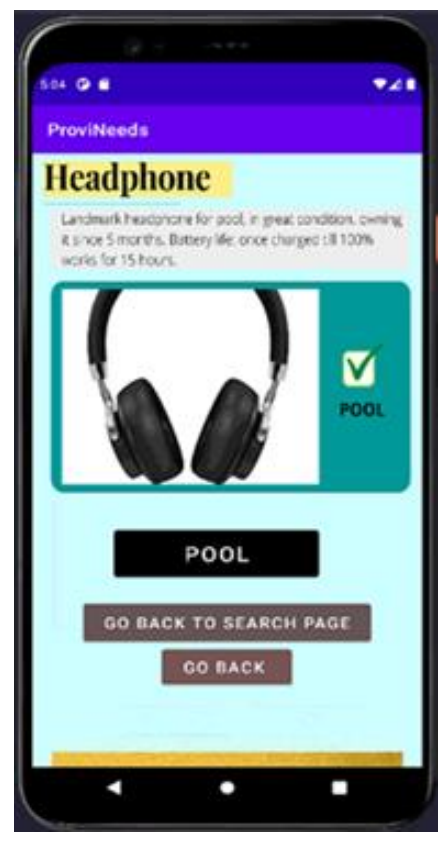

Figure 8 Product Description Page

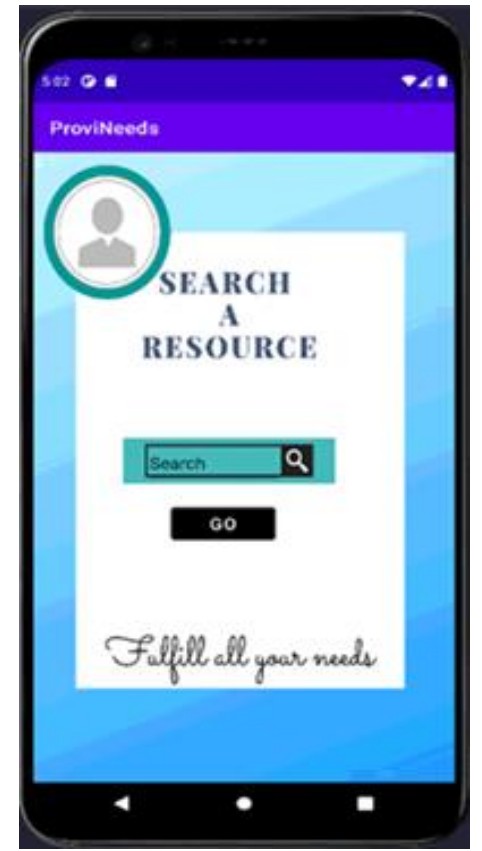

Figure 6 Search Page

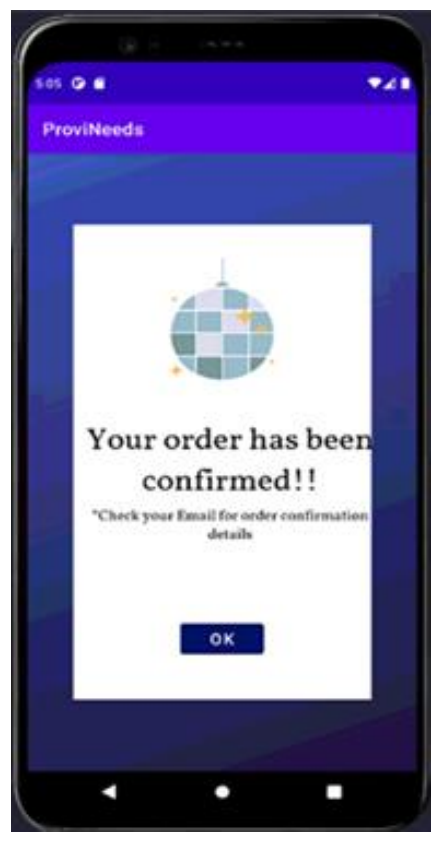

Figure 9 Confirm Page

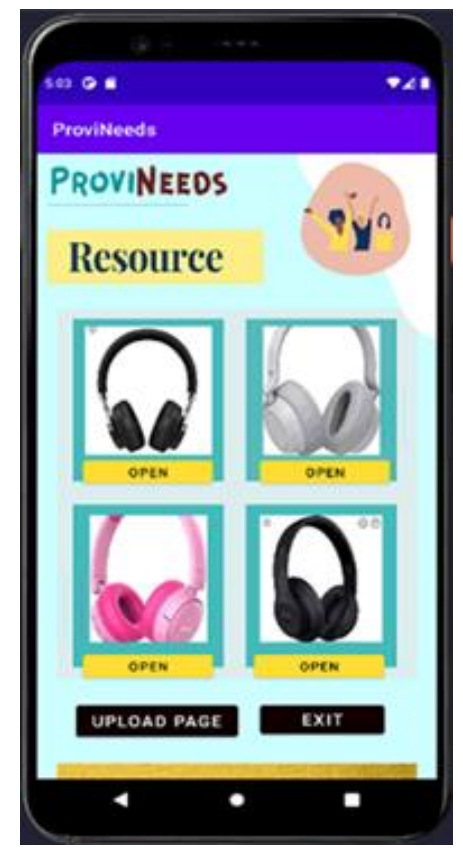

Figure 7 Product Page

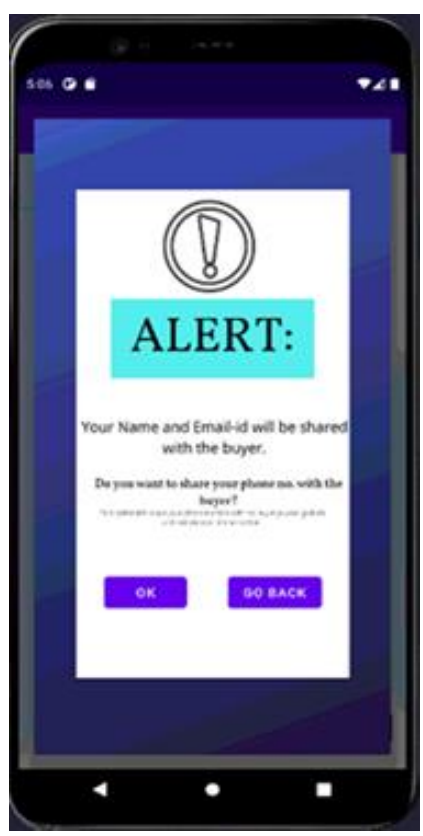

Figure 10 Alert Dialog Box 


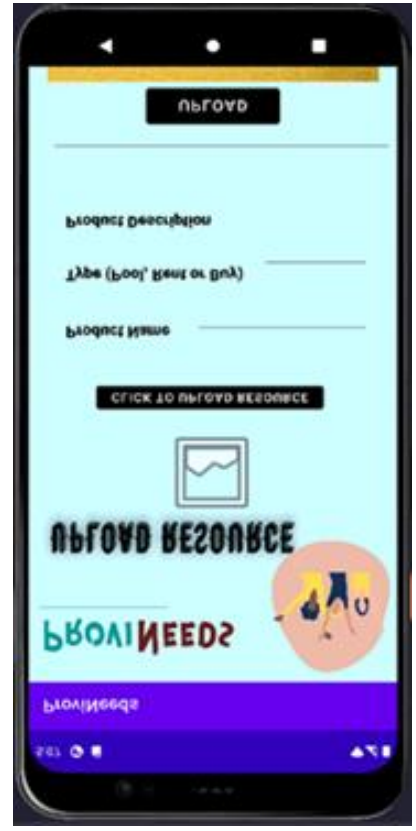

Figure 11 Upload Page

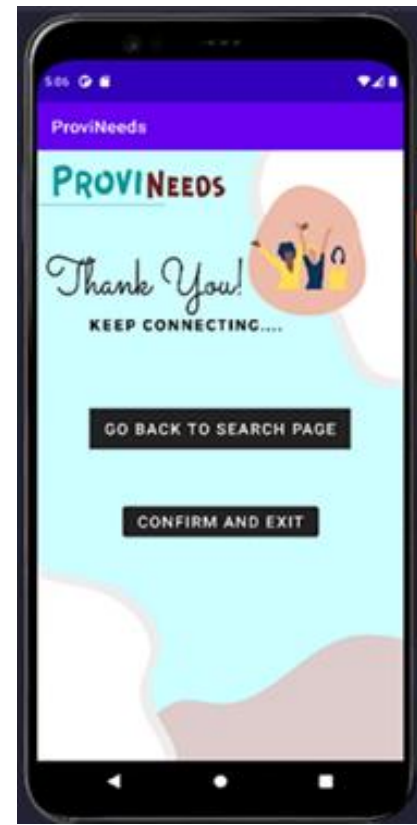

Figure 12 Exit page

\section{Features of the portal}

- The user can search for required resources on the portal.

- The user can upload the extra resources they have for either pool, buy or rent.

- The app has separate forms for each page. Every form has validation function, email and password pattern check function and empty field check function.

- The forms in the portal are connected to real-time database and show error message if the data is not stored.

- The portal also has functions of upload profile and product image.

- Forget password link will help the users in retrieving their password.

- The user can sign up through their google accounts as well.

- The users will be able to chat with each other due to an inbuilt chat system.

- The portal will have a chat bot that will help in solving all the queries of the users.

- The users will be able to choose from buy, pool and rent option for the respective products.

- The data of the user is stored properly and the user gets alert message when their data is being shared.

\section{Conclusion}

After a thorough study about other existing system and technologies, proposed student support system for resource pooling intends to make a difference in the society by helping one of the most important communities of the society i.e., the student community. Many studies reviewed during the study explains that there has been research on these problems faced by students, but there is no specific solution provided for them.

This option of earning a little extra, getting resources for free and being able to establish a community sounds very good and this system will help in starting a technology that only focuses on student's needs, financial issues and helps them in developing a social community. With the help of this system, current study also contributes towards the health and wellness of the country. If the issues of students are solved easily then they will be able to focus more on their studies and will contribute more towards the country and the social community will help in having a healthy mental environment. Current study concludes that the ProviNeeds: student support system helps in solving problems of the student community in an innovative way. 


\section{Compliance with ethical standards}

\section{Acknowledgments}

Our special thanks to Symbiosis Institute of Computer Studies and Research for giving us opportunity to complete this research work and necessary support

\section{Disclosure of conflict of interest}

Hereby, all the authors declare no conflict of interest.

\section{References}

[1] Rauniar R, Rawski G, Crumbly J, Simms J. C2C online auction website performance: Buyer's perspective. Journal of Electronic Commerce Research. 2009 May 1;10(2):56.

[2] Jebessa M, Lemu BN, Nguse TM. Exploring the effects of lack of pocket money on undergraduate clinical year health science students' learning activities. medRxiv. 2019 Oct 29:19009985.

[3] Shelton J. The Cost of Renting versus Owning a Home. Land Economics. 1968; 44(1): 59-72.

[4] Pantazis C, Gordon D, Levitas R, editors. Poverty and social exclusion in Britain: The millennium survey. Policy Press; 2006 Jan 19.

[5] Williams CC. The new barter economy: an appraisal of Local Exchange and Trading Systems (LETS). Journal of Public Policy. 1996 Jan;16(1):85-101.

[6] Demirkol S, Getir S, Challenger M, Kardas G. Development of an Agent based E-barter System. In2011 International Symposium on Innovations in Intelligent Systems and Applications 2011 Jun 15 (pp. 193-198). IEEE.

[7] Chalal R, Ghomari AR. An approach for a bidding process knowledge capitalization. world academy of science, Engineering and technology. 2006;13(7):293-7.

[8] Cao Y. Research on application of the Internet of things technology in financial leasing of intelligent manufacturing enterprises. The International Journal of Advanced Manufacturing Technology. 2020 Mar;107(3):1061-70.

[9] Roseland M. Sustainable community development: integrating environmental, economic, and social objectives. Progress in planning. 2000 Jan 1;54(2):73-132.

[10] Dillahunt TR, Simioni S, Xu X. Online grocery delivery services: An opportunity to address food disparities in transportation-scarce areas. InProceedings of the 2019 CHI Conference on Human Factors in Computing Systems 2019 May 2 (pp. 1-15).

[11] Rauniar R, Rawski G, Crumbly J, Simms J. C2C online auction website performance: Buyer's perspective. Journal of Electronic Commerce Research. 2009 May 1;10(2):56.

[12] Jebessa M, Lemu BN, Nguse TM. Exploring the effects of lack of pocket money on undergraduate clinical year health science students' learning activities. medRxiv. 2019 Oct 29:19009985.

[13] Shelton JP. The cost of renting versus owning a home. Land Economics. 1968 Feb 1;44(1):59-72.

[14] Pantazis C, Gordon D, Levitas R, editors. Poverty and social exclusion in Britain: The millennium survey. Policy Press; 2006 Jan 19.

[15] Williams CC. The new barter economy: an appraisal of Local Exchange and Trading Systems (LETS). Journal of Public Policy. 1996 Jan;16(1):85-101.

[16] Demirkol S, Getir S, Challenger M, Kardas G. Development of an Agent based E-barter System. In2011 International Symposium on Innovations in Intelligent Systems and Applications 2011 Jun 15 (pp. 193-198). IEEE.

[17] Chalal R, Ghomari AR. An approach for a bidding process knowledge capitalization. world academy of science, Engineering and technology. 2006;13(7):293-7. 
[18] Cao Y. Research on application of the Internet of things technology in financial leasing of intelligent manufacturing enterprises. The International Journal of Advanced Manufacturing Technology. 2020 Mar;107(3):1061-70.

[19] Roseland M. Economic instruments for sustainable community development. Local Environment. 1996 Jun 1;1(2):197-210.

[20] Dillahunt TR, Simioni S, Xu X. Online grocery delivery services: An opportunity to address food disparities in transportation-scarce areas. InProceedings of the 2019 CHI Conference on Human Factors in Computing Systems 2019 May 2 (pp. 1-15).

[21] Boyer KK, Hult GT. Customer behavior in an online ordering application: A decision scoring model. Decision Sciences. 2005 Nov;36(4):569-98.

[22] Mkansi M, de Leeuw S, Amosun O. Mobile application supported urban-township e-grocery distribution. International Journal of Physical Distribution \& Logistics Management. 2019 Nov 14.

[23] Antoniadis P, Le Grand B. Incentives for resource sharing in self-organized communities: From economics to social psychology. In2007 2nd International Conference on Digital Information Management 2007 Oct 28 (Vol. 2 , pp. 756-761). IEEE.

[24] Liberman Z, Shaw A. Children use partial resource sharing as a cue to friendship. Journal of Experimental Child Psychology. 2017 Jul 1; 159:96-109.

[25] Diga M, Kelleher T. Social media use, perceptions of decision-making power, and public relations roles. Public Relations Review. 2009 Nov 1;35(4):440-2.

[26] Ciobanu A. The role of student services in the improving of student experience in higher education. ProcediaSocial and Behavioral Sciences. 2013 Oct 10; 92:169-73.

[27] Choi S, Gudmunson CG, Griesdorn TS, Hong GS. Assessing college student needs for comprehensive financial counseling. Journal of Financial Counseling and Planning. 2016 Jan 1;27(2):158-71.

[28] Van Welie M, Eliëns A. Chatting on the Web. InProceedings of the ERCIM W4G workshop on CSCW and the Web, Sankt Augustin, Germany, February 19961996 Feb.

[29] Yeh JC, Hsiao KL, Yang WN. A study of purchasing behavior in Taiwan's online auction websites: Effects of uncertainty and gender differences. Internet Research. 2012 Jan 27.

[30] Holla S, Katti MM. Android based mobile application development and its security. International Journal of Computer Trends and Technology. 2012 Jun;3(3):486-90. 